STUDIES IN ENGLISH LITERATURE

Volume $L X X X V$ 



\title{
SHAKESPEARE AND THE ARCHPRIEST CONTROVERSY A Study of Some New Sources
}

\author{
by \\ DAVID KAULA \\ University of Western Ontario
}

1975

MOUTON

THE HAGUE - PARIS 


\begin{abstract}
(C) Copyright 1975 in The Netherlands
Mouton \& Co. N.V., Publishers, The Hague

No part of this book may be translated or reproduced in any form, by print, photoprint, microfilm, or any other means, without written permission from the publishers
\end{abstract}

LIBRARY OF CONGRESS CATALOG CARD NUMBER: 74-78510

Printed in Belgium by N.I.C.I., Ghent. 